\title{
PENGARUH VARIASI SELIMUT BETON TERHADAP KAPASITAS BALOK PERSEGI DALAM MENAHAN KECEPATAN KOROSI
}

\author{
Herry Henry Roberth \\ herryroberth1965@gmail.com \\ Teknik Sipil Politeknik Negeri Ambon
}

\begin{abstract}
ABSTRAK
Selimut beton atau concrete ducking atau disebut juga pelindung tulangan cukup penting dan sangat menentukan keamanan dari tulangan pada struktur beton bertulang terutama pada struktur yang berada di lingkungan yang bebas dan agresif. Di Maluku umumnya pembangunan infrastruktur terutama jembatan lebih banyak dibangun dalam jarak $<1 \mathrm{~km}$ dari garis pantai. Ini menyebabkan struktur dari jembatan tersebut sangat terpengaruh terhadap agresifitas dari ion klorida penyebab korosi. Hal ini menyebabkan keamanan dan umur struktur akan semakin pendek mungkin saja kurang dari umur rencana.

Penelitian ini bertujuan untuk mengetahui sejauh mana pengaruh selimut beton dalam mencegah laju korosi dan juga kapasitas lentur dan geser dari struktur yang di desain sebagai suatu model dengan menggunakan pembebanan dari AASTHO (American Associates of System Transportation and Highway Organization) yaitu AASTHO-LRFD-1998.

Kesimpulan dari hasil penelitian, bahwa semakin tebal selimut beton maka semakin baik dalam menahan laju korosi namun semakin kecil kapasitas lentur dan geser yang dihasilkan. Diperoleh juga bahwa faktor air-semen, $w / c$ juga turut mempengaruhi kapasitas lentur dan geser balok. Semakin Kecil Nilai $w / c$ maka semakin tinggi kapasitas lentur dan geser balok.

Penelitian ini masih belum begitu intensif disebabkan belum mengetahui keandalan struktur dalam arti umur layan struktur akibat pengaruh korosi sehingga perlu adanya penelitian yang berkelanjutan.
\end{abstract}

Kata Kunci : Selimut Beton, Kapasitas Balok, Beton Bertulang, Jembatan, Korosi.

\section{PENDAHULUAN}

\subsection{Latar Belakang}

Tiap struktur beton dapat terkena pengaruh korosi terutama untuk struktur yang tidak terlindung atau dekat dengan laut seperti Indonesia yang memiliki garis pantai sekitar $74.000 \mathrm{~km}$. Pengaruh air laut terhadap komponen struktur bangunan beton bertulang menyebabkan terjadi karatan atau korosi pada tulangannya. Berkurangnya kinerja struktur disebabkan korosi tulangan, mengakibatkan diameter tulangan berkurang dan luas tulangan tersisa $<$ luas tulangan mula-mula. Berdasarkan perkiraan para ahli, kerusakan akibat korosi di Indonesia mencapai $1.5 \%$ dari GNP dan industri minyak kerusakan mencapai $15 \%$ dari nilai instalasinya (Darmawan M.S., 2006).

Stewart M.G., (2004), menyatakan korosi pada struktur beton bertulang dapat berakibat pada segi pelayanan (serviceability) dan jika tidak dilakukan perawatan atau pencegahan dengan perbaikan pada struktur maka menyebabkan keruntuhan. Hal ini dapat dihindari dengan dibuat kerangkakerja (framework) yang memperkirakan kinerja struktur sebelum dan sesudah terkena pengaruh korosi sehingga dapat dilakukan tindakan pencegahan. Kerangkakerja dimaksud adalah gabungan antara model struktur, model pembebanan dan model korosi yang dianalisis terhadap kuat lentur dan geser.

Dalam penelitian "Pengaruh Variasi Selimut Beton Terhadap Kapasitas Balok Persegi Dalam Menahan Kecepatan Korosi" ini dibuat model korosi beton bertulang pada struktur balok jembatan. 


\subsection{Perumusan Masalah}

Rumusan masalah yang ditelaah dalam penelitian ini meliputi :

a) Bagaimana mengetahui efek korosi terhadap kekuatan balok;

b) Bagaimana mengetahui kinerja struktur yang terkena pengaruh korosi.

\subsection{Maksud dan Tujuan Penelitian}

a) Mengetahui efek korosi terhadap kekuatan balok;

b) Mengetahui kinerja struktur terkena pengaruh korosi.

\subsection{Batasan Permasalahan}

Batasan permasalahan dalam penelitian ini, dibatasi pada :

a) Pendekatan metematik bersifat deterministik;

b) Pengaruh korosi hanya akibat klorida;

c) Material beton merupakan beton normal tanpa bahan additif dimana elemen balok dan pelat mutu sama;

d) Jenis korosi terjadi diasumsikan merupakan korosi seragam (uniform corrosion) dimana $i_{\text {corr }}$ ditetapkan;

e) Retak tidak ditinjau;

f) Keandalan struktur dievaluasi terhadap kapasitas lentur dan geser serta lendutan;

g) Pembebanan berdasarkan AASTHO-LRFD-1998 tentang Standar Pembebanan Untuk Jembatan serta Desain Struktur Beton menggunakan SNI T12-2004;

h) Balok gelagar jembatan yang ditinjau dan dievaluasi yaitu balok beton bertulang yang terkena pengaruh korosi (bukan suatu sistem).

\subsection{Manfaat Penelitian}

Merupakan suatu studi untuk dapat menentukan kinerja struktur beton bertulang pada elemen struktur balok jembatan dalam selang waktu 50 tahun.

\section{KAJIAN TEORI DAN METODE}

\subsection{Korosi Pada Struktur Bangunan}

- Pengertian Korosi

Korosi merupakan proses alami yang terus berlangsung seiring waktu terutama didaerah pengaruh korosi tinggi (lingkungan agresif). Menurut Cantrell A., (2002), karbonat $\left(\mathrm{O}_{2}\right)$ dan ion klorida $\left(\mathrm{Cl}^{-}\right)$turut mempengaruhi proses korosi (Gambar 1).
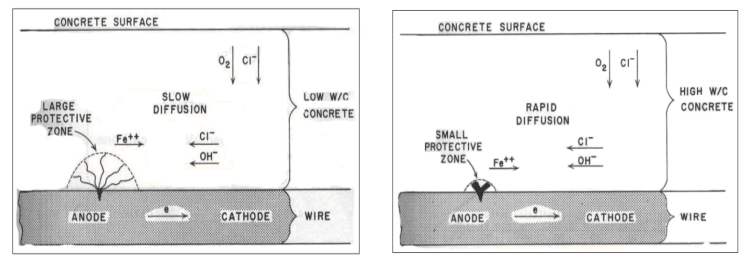

Gambar 1. Skema korosi beton (a) w/c rendah dan (b) w/c tinggi (Cantrell A., 2002)

Menuryt Stewart M.G. dan Rosowsky D.V., (1998), proses korosi tulangan terdiri dari dua tahapan, yaitu:

a. Initiation (inisiasi) yaitu masuknya ion klorida $\left(\mathrm{Cl}^{-}\right)$kedalam beton hingga mencapai tulangan dan terakumulasi pada konsentrasi tertentu sampai terjadi korosi. Korosi inisiasi, tulangan masih tetap utuh dan kekuatan struktur stabil (lihat Gambar 3).

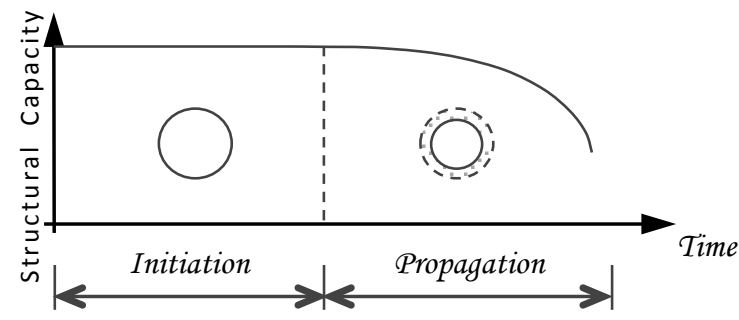

Gambar 2. Kinerja struktur akibat pengaruh korosi

(Darmawan M.S., 2006)

b. Propagation (propagasi) yaitu korosi tulangan yang mengurangi luas tulangan (metal loss) sehingga terjadi penurunan kekuatan struktur (Gambar 2).

Proses korosi alami terjadi dalam jangka waktu cukup lama ( $>5$ tahun). Hasil Penelitian Andrade C. dan Alonso C. (1994) serta Millard (1993) bahwa kecepatan korosi alami, $i_{\text {corr }}$ dapat mencapai $100 \mathrm{~mA} / \mathrm{cm}^{2}$ atau $1,160 \mathrm{~mm} /$ year.

\section{- Model Korosi}

* Korosi Inisiasi

Korosi inisiasi : proses masuknya ion klorida $\left(\mathrm{Cl}^{-}\right)$kedalam beton hingga mendekati tulangan dan terakumulasi hingga mencapai konsentrasi tertentu dan terjadinya korosi. Saat terjadi korosi inisiasi, tidak ada pengurangan kekuatan struktur. Stewart M.G. \& Rosowsky D.V., (1998), proses korosi inisiasi dimodelkan berdasarkan Hukum Fick Kedua (Fick's Second Law).

\section{* Korosi Propagasi}

Korosi propagasi : proses masuknya ion klorida $\left(\mathrm{Cl}^{-}\right)$menembus lapisan pasif tulangan sehingga menyebabkan penurunan kekuatan 
struktur. Korosi propagasi dibagi dua model: korosi setempat (pitting corrosion) dan korosi seragam (uniform corrosion).

Model korosi Val D.V. \& Melchers R.E., (1997):

$$
\mathrm{D}_{\mathrm{D}}(T) / 2=0.0232 \mathrm{i}_{\text {corr }} T
$$
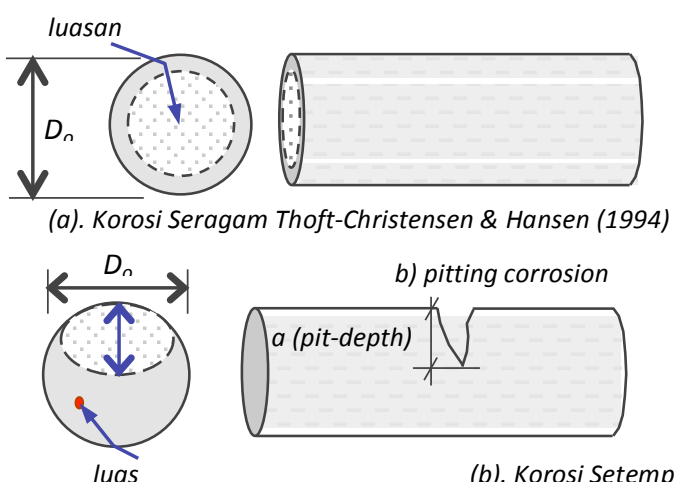

(b). Korosi Setempat

Gambar 3. Model korosi tulangan (Darmawan M.S.)

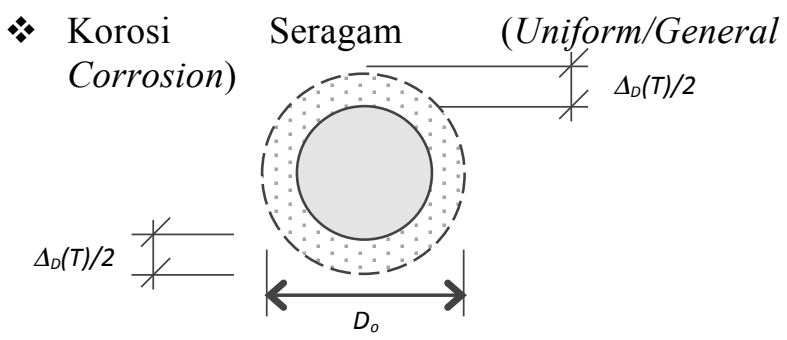

Gambar 4. Uniform Corrosion Model (Stewart M.G)

Luas Tulangan dalam waktu $T$ (general corrosion),

$$
A_{\mathrm{st}}(T)=\left(\frac{1}{4}\right) n \pi\left(D_{0}-2 P_{a v}\right)^{2}
$$

Subtitusikan Persamaan 1 dan 2, diperoleh:

$$
A_{\text {st }}(T)=\left(\frac{1}{4}\right) n \pi\left(D_{0}-0.0232 i_{\text {corr }} T\right)^{2}
$$

* Kecepatan Korosi ( $\left.\mathrm{i}_{\text {corr }}\right)$

$$
i_{c o r r}(1)=\frac{37.8\left(1-\frac{w}{c}\right)^{-1.64}}{p}
$$

dimana

$i_{\text {corr }}(1)$ : kecepatan korosi propagasi $\left(\mathrm{mA} / \mathrm{cm}^{2}\right)$;

$w / c \quad:$ faktor air-semen;

$p \quad$ : tebal selimut beton (mm)

Sedangkan pada penampang balok beton bertulang, luasan tulangan total $A_{\text {st }}$ yang tersisa di selang waktu tertentu $T$ untuk korosi menyeluruh (general corrosion),

$$
\Delta_{\mathrm{D}}(T) / 2=0.0232 \mathrm{i}_{\text {corr }} T
$$

dimana,

$\Delta_{D}(T) / 2 \quad$ : kedalaman korosi propagasi seragam ( $\mathrm{mm} / \mathrm{tahun}$;

$i_{\text {corr }} \quad$ : kecepatan korosi alami

$(1 \mathrm{~mA} / \mathrm{cm} 2=11.6 \mathrm{~mm} / \mathrm{tahun})$;

$T \quad$ : waktu mulai korosi propagasi (tahun)

$$
A_{\mathrm{st}}(T)=\left(\frac{1}{4}\right) n \pi\left(D_{0}-2 P_{a v}\right)^{2}
$$

Subtitusikan Pers. 4 ke Pers. 6, diperoleh:

$$
A_{\mathrm{st}}(T)=\left(\frac{1}{4}\right) n \pi\left(D_{0}-\Delta_{D}(T) / 2\right)^{2}
$$

Dari Persamaan 5 ke Pers. 7, diperoleh:

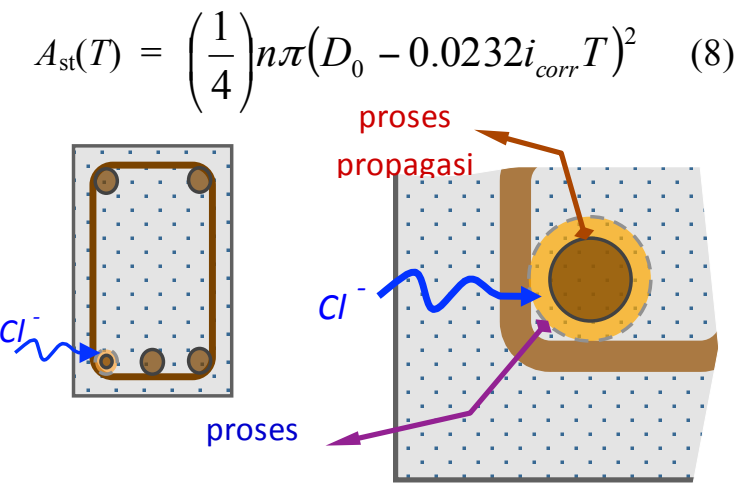

Gambar 5. Penampang tulangan terkena pengaruh

\section{- Variabel Pengaruh Korosi}

Variabel yang mempengaruhi terjadinya proses korosi dijelaskan berikut,

a. Kecepatan Korosi $\left(i_{\text {corr }}(1)=i_{\text {corr }}\right) \rightarrow$ Pers. 4

b. Faktor Air-Semen, w/c (Bolomey's formula),

$$
w / c=\frac{27}{f_{c y l}^{\prime}+13.5}
$$

c. Mutu Beton $\left(f_{c}^{\prime}\right)$,

Mutu beton, $f_{c}$ lebih tinggi akan memperlambat proses korosi.

d. Selimut Beton $(p)$,

Selimut beton, $p$ juga berpengaruh terhadap proses korosi. Semakin tebal selimut beton (sesuai peraturan dan spesifikasi), akan baik dalam proses perlambatan korosi itu sendiri tetapi sebaliknya.

\subsection{Model Struktur dan Model Pembebanan}

- Model Struktur

Model struktur dalam penelitian ini berupa struktur balok beton bertulang dengan tumpuan 
sederhana jembatan diaplikasikan (Gbr. 7a dan $7 b)$.

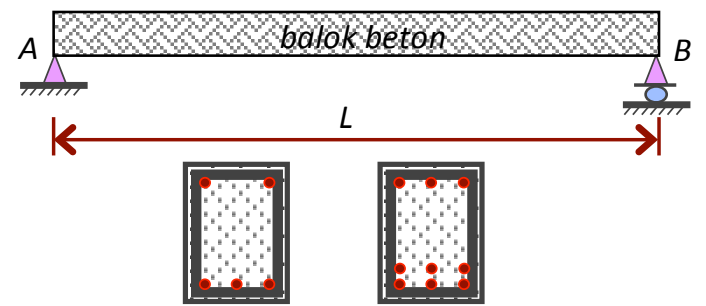

Gambar 6. Prototype balok dan penampang beton bertulang

- Model Pembebanan

Beban-beban bekerja pada struktur balok berupa beban mati (berat sendiri struktur) dan beban hidup.

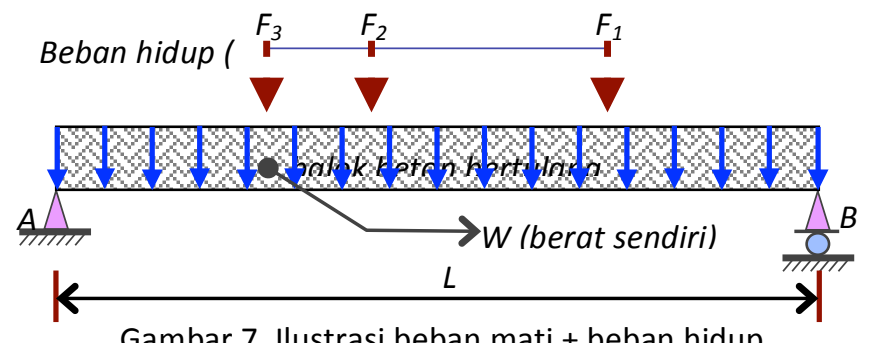

2.3. Analisis Penampang Lentur dan Geser Akibat Pengaruh Korosi

* Analisis Lentur

- Balok Tulangan Tunggal

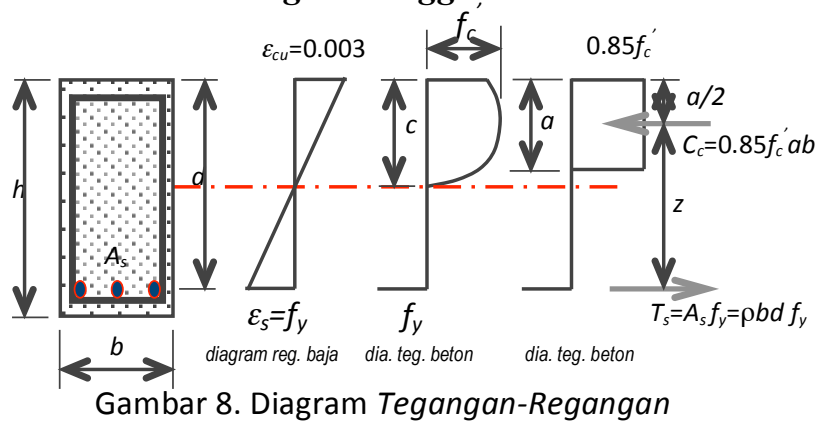

Gaya yang bekerja tanpa Korosi,

$$
T_{\mathrm{s}} \quad=A_{\mathrm{s}} f_{\mathrm{y}}
$$

Momen Nominal tanpa Korosi,

$$
M_{\mathrm{n}}=T_{\mathrm{s}} \mathrm{z}=A_{\mathrm{s}} f_{\mathrm{y}}(d-a / 2)
$$

Gaya yang bekerja dengan Korosi,

$$
T_{\mathrm{s}}(T)=A_{\mathrm{s}}(T) \cdot f_{\mathrm{y}}
$$

Luasan Tulangan Terkorosi,

$$
A_{\mathrm{st}}(T)=\left(\frac{1}{4}\right) n \pi\left(D_{0}-0.0232 i_{\text {corr }} T\right)^{2}
$$

Pers. 12 subtitusi ke Pers. 13 sehingga gaya yang bekerja dengan Korosi menjadi,

$$
T_{\mathrm{s}}(T)=\left(\frac{1}{4}\right) n \pi\left(D_{0}-0.0232 i_{\text {corr }} T\right)^{2} f_{\mathrm{y}}
$$

Momen Nominal dengan Korosi,

$$
M_{\mathrm{n}}(T)=T_{\mathrm{s}}(T) \mathrm{z}=A_{\mathrm{s}}(T) \cdot f_{\mathrm{y}}(d-a / 2)
$$

Subtitusi Pers. 8 ke Pers. 15 untuk Momen Nominal dengan Korosi,

$$
\begin{aligned}
M_{n}(T)=A_{s}(T) \cdot f_{y} z= & \left(\frac{1}{4}\right) n \pi\left(D_{o}-0.0232 i_{c o r r} T\right)^{2} . \\
& f_{y} \cdot(d-a / 2)
\end{aligned}
$$

\section{- Balok Tulangan Ganda}

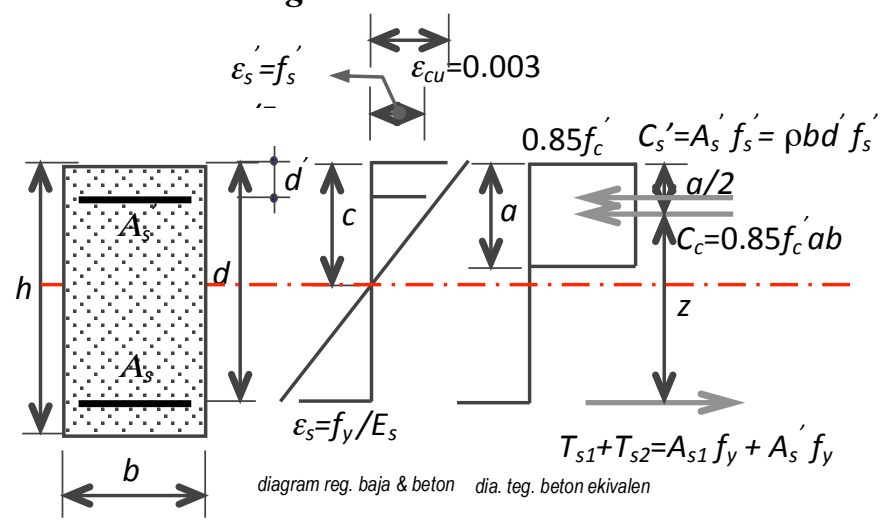

Gambar 9. Diagram Tegangan-Regangan

$A_{\mathrm{s}}=A_{\mathrm{s} 1}+A_{\mathrm{s} 2} \mathrm{~g}$ tulangan tarik ;

$A_{\mathrm{s}}{ }^{\prime} \quad=A_{\mathrm{s} 2} \mathrm{~g}$ tulangan tekan

$A_{\mathrm{s} 1}=A_{\mathrm{s}}-A_{\mathrm{s}}{ }^{\prime} ; \mathrm{z}=d-(a / 2)$

Gaya yang bekerja tanpa Korosi,

$$
T_{\mathrm{s}}=T_{\mathrm{s} 1}+T_{\mathrm{s} 2}=A_{\mathrm{s} 1} f_{\mathrm{y}}+A_{\mathrm{s}}{ }^{\prime} f_{\mathrm{s}}
$$

Momen Nominal tanpa Korosi,

$$
\begin{aligned}
M_{\mathrm{n}} & =M_{\mathrm{n} 1}+M_{\mathrm{n} 2}=T_{\mathrm{s} 1} \mathrm{z}+T_{\mathrm{s} 2}\left(d-d^{\prime}\right) \\
& =A_{\mathrm{s} 1} f_{\mathrm{y}}(d-a / 2)+A_{\mathrm{s}}^{\prime} f_{\mathrm{s}}^{\prime}\left(d-d^{\prime}\right)
\end{aligned}
$$

Gaya yang bekerja dengan Korosi,

$$
\begin{aligned}
T_{s}(T) & =T_{s 1}(T)+T_{s 2}(T) \\
& =A_{s 1}(T) f_{y}+A_{s^{\prime}}(T) \cdot f_{s^{\prime}}
\end{aligned}
$$

Dari Pers. 13, diperoleh,

$$
A_{\mathrm{st}}(T)=\left(\frac{1}{4}\right) n \pi\left(D_{0}-0.0232 i_{\text {corr }} T\right)^{2}
$$

Pers. 8 subtitusi ke Pers. 19 sehingga Gaya yang bekerja dengan Korosi menjadi,

$$
T_{\mathrm{s}}(T)=A_{\mathrm{s} 1}(T) \cdot f_{\mathrm{y}}+A_{\mathrm{s}}{ }^{\prime}(T) \cdot f_{\mathrm{s}}{ }^{\prime}
$$

Sehingga,

$$
\begin{aligned}
T_{\mathrm{s}}(T) & =\left(\frac{1}{4}\right) n \pi\left(D_{0}-0.0232 i_{\text {corr }} T\right)^{2} \cdot f_{\mathrm{y}} \\
& +\left(\frac{1}{4}\right) n \pi\left(D_{0}-0.0232 i_{\text {corr }} T\right)^{2} \cdot f_{\mathrm{s}}
\end{aligned}
$$


Momen Nominal dengan Korosi,

$$
\begin{aligned}
& M_{\mathrm{n}}(T)= A_{\mathrm{s} 1}(T) \cdot f_{\mathrm{y} . \mathrm{z}}+A_{\mathrm{s}}{ }^{\prime}(T) \cdot f_{\mathrm{s}}{ }^{\prime}\left(d-d^{\prime}\right) \\
&=\left(\frac{1}{4}\right) n \pi\left(D_{0}-0.0232 i_{\text {corr }} T\right)^{2} \cdot f_{\mathrm{y}} . \\
&+\left(\frac{1}{4}\right) n \pi\left(D_{0}-0.0232 i_{\text {corr }} T\right)^{2} \\
& . f_{\mathrm{s}}^{\prime} \cdot\left(d-d^{\prime}\right)
\end{aligned}
$$

Bilamana $c<h_{\mathrm{f}}$ (c pada Pers. 22), maka :

$$
\begin{aligned}
\mathrm{C} & =\mathrm{C}_{\mathrm{C}}=0.85 \cdot f_{\mathrm{c}} \cdot a \cdot b \\
C_{\mathrm{S}} & =A_{\mathrm{s}}{ }^{\prime} \cdot f_{\mathrm{y}} \\
T & =T_{\mathrm{s}}+T_{\mathrm{s}}, \\
T_{\mathrm{s}} & =A_{\mathrm{s}} \cdot f_{\mathrm{y}} \\
T_{\mathrm{s}}{ }^{\prime} & =A_{\mathrm{s}}{ }^{\prime} \cdot f_{\mathrm{s}}, \\
f_{\mathrm{s}} & =\varepsilon_{\mathrm{cu}} \cdot E_{\mathrm{s}} \cdot\left(\frac{\beta_{1} \cdot d^{\prime}}{a}-1\right)
\end{aligned}
$$

Kapasitas Momen Terkorosi Sebelum Leleh, $\phi M_{\mathrm{n}}(T)$ :

$\phi \mathrm{M}_{\mathrm{n}}(T)=$

$\phi\left[\left\{\left(\left(\frac{1}{4}\right) n \pi\left(D_{0}-0.0232 i_{c o r r} T\right)^{2}\right)-\left(\left(\frac{1}{4}\right) n \pi\left(D_{0}{ }^{\prime}-0.0232 i_{c o r r} T\right)^{2}\right)\right\} f_{y}\right]\left(d-\frac{a}{2}\right)$

$+\left\{\left(\left(\frac{1}{4}\right) n \pi\left(D_{0}{ }^{\prime}-0.0232 i_{\text {corr }} T\right)^{2}\right) f_{s}^{\prime}\right\}\left(d-d^{\prime}\right)$

Kapasitas Momen Terkorosi Sesudah Leleh, $\phi M_{\mathrm{n}}(T)$ :

$\phi \mathrm{M}_{\mathrm{n}}(T)=$

$\phi\left[\left\{\left(\left(\frac{1}{4}\right) n \pi\left(D_{0}-0.0232 i_{\text {corr }} T\right)^{2}\right)-\left(\left(\frac{1}{4}\right) n \pi\left(D_{0}^{\prime}-0.0232 i_{\text {corr }}\right)^{2}\right)\right] f_{y}\right]\left(d-\frac{a}{2}\right)$

$$
+\left\{\left(\left(\frac{1}{4}\right) n \pi\left(D_{0}^{\prime}-0.0232 i_{\text {corr }} T\right)^{2}\right) f_{y}\right\}\left(d-d^{\prime}\right)
$$

Dari hasil yang diperoleh periksalah sesuai syarat:

$$
\begin{aligned}
M_{\mathrm{u}} \leq \phi M_{\mathrm{n}} & \rightarrow \text { tanpa korosi } \\
M_{\mathrm{u}} \leq \phi M_{\mathrm{n}}(T) & \rightarrow \text { dengan korosi }
\end{aligned}
$$

bilamana,

$$
\begin{aligned}
& M_{\mathrm{u}}<\phi M_{\mathrm{n}}(T) \rightarrow(\text { safe }) \\
& M_{\mathrm{u}}>\phi M_{\mathrm{n}}(T) \rightarrow(\text { fail })
\end{aligned}
$$

\section{- Analisis Geser}

Luas Tulangan Geser dengan Korosi :

$$
A_{\mathrm{v}}(T)=2 \cdot\left(\frac{1}{4}\right) \pi\left(D_{0}-0.0232 i_{\text {corr }} T\right)^{2}
$$

Kuat Geser Tulangan dengan Korosi,

$$
V_{\mathrm{S}}(T)=\frac{2 \cdot \frac{1}{4} \cdot \pi\left(D_{0}-0.0232 i_{\text {corr }} T\right)^{2} \cdot f_{y} \cdot d}{s}
$$

Kuat Geser Nominal dengan Korosi,

$$
V_{\mathrm{n}}(T)=V_{\mathrm{c}}+V_{\mathrm{s}}(T)
$$

$$
\begin{aligned}
& =\left(\frac{\sqrt{f_{c}^{\prime}}}{6}\right) b_{w} \cdot d \\
& +\frac{2 \cdot \frac{1}{4} \cdot \pi\left(D_{0}-0.0232 i_{c o r r} T\right)^{2} \cdot f_{y} \cdot d}{s}
\end{aligned}
$$

Periksa sesuai SNI T-12-2004 Pasal 5.2.1 hal. 31:

$$
\begin{aligned}
& V_{\mathrm{u}} \leq \phi V_{\mathrm{n}} \rightarrow \text { tanpa korosi } \\
& V_{\mathrm{u}} \leq \phi V_{\mathrm{n}}(T) \rightarrow \text { dengan korosi }
\end{aligned}
$$

bilamana, $\quad V_{\mathrm{u}}<\phi V_{\mathrm{n}}(T) \rightarrow$ (safe)

$$
V_{\mathrm{u}}>\phi V_{\mathrm{n}}(T) \rightarrow(\text { fail })
$$

\subsection{Metode}

\section{* Parameter Penelitian}

- Variabel deterministik : Panjang bentang (L)

- Variabel non deterministik :

Model korosi ; Beban mati (berat sendiri) ;

Beban hidup (traffic load); Mutu beton $\left(f_{\mathrm{c}}\right.$ '); Mutu baja $\left(f_{\mathrm{y}}\right)$; Selimut beton $(p)$;

Ratio air-semen $(w / c)$

\section{- Diagram Alir Proses Penelitian}
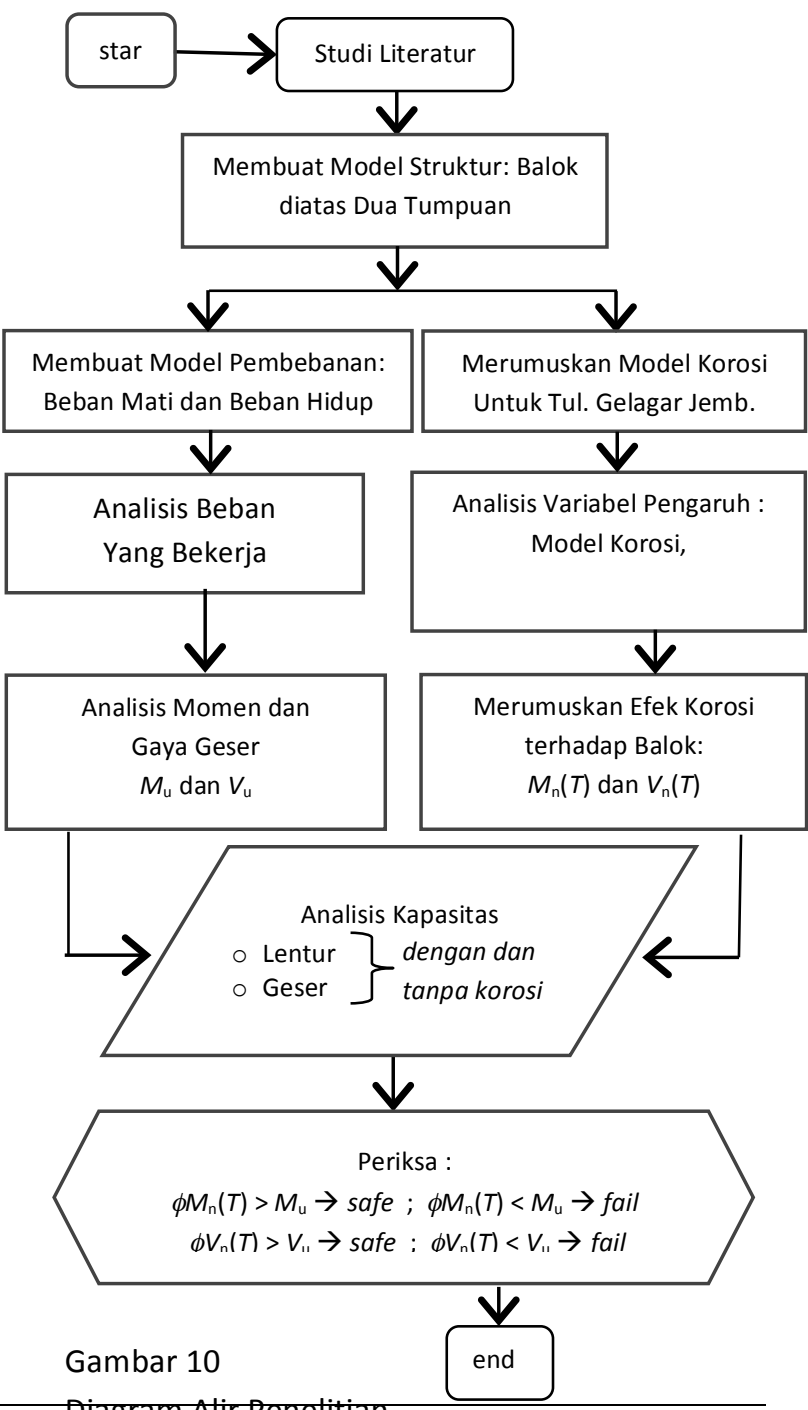

Diagram Alir Penelitian 


\section{HASIL DAN PEMBAHASAN}

\subsection{Memodelkan Struktur Beban Yang Bekerja \\ * Model Struktur}

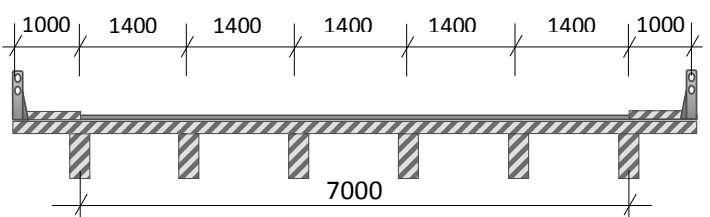

Gambar 11. Potongan melintang jembatan dgn. trotoar

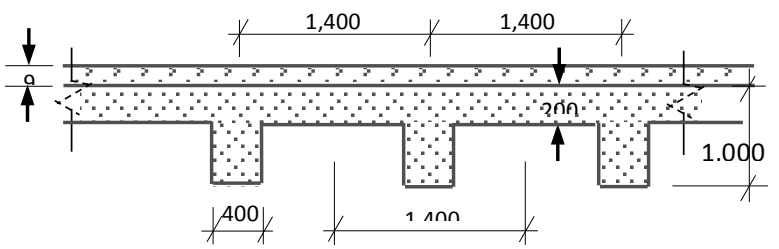

Gambar 12. Typical balok girder jembatan span 12,00

* Model Beban Rencana dan Desain Balok

\section{Beban Mati}

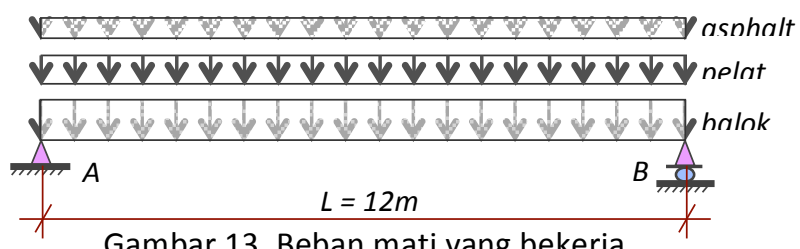

Beban mati yang bekerja, $\left(\mathrm{q}_{1}\right)=1.9092 \mathrm{t} / \mathrm{m}$

Momen akibat beban mati yang bekerja $\left(M_{1}\right)$,

$$
M_{1}=(1 / 8) \mathrm{qa} \mathrm{L}^{2}=34.3656 \mathrm{t} . \mathrm{m}
$$

\section{Beban Hidup (AASTHO-LRFD-1998)}

Momen dari beban hidup kendaraan sebesar:

$M_{2}=\mathrm{GDF} \times \mathrm{M}_{2}=0.5260 \times 76.14=40.0640 \mathrm{t} . \mathrm{m}$

Sehingga momen total yang bekerja, $M_{\mathrm{u}}$ :

$$
\mathrm{M}_{\mathrm{u}}=1,167,581,020 \text { N.mm }
$$

\subsection{Hasil Penelitian}

\section{* Hasil Pemeriksaan Lendutan}

Untuk Lendutan Ijin,

$$
\text { Si }=\frac{1}{800} L=\frac{1}{800} \cdot 12000=15 \mathrm{~mm}
$$

Lendutan Total,

$\delta_{\mathrm{T}}=1.40+1.19=2.60 \mathrm{~mm}(\downarrow)<\mathrm{di}=15 \mathrm{~mm}$

\section{* Hasil Analisis Kecepatan Korosi}

Tabel 1. Kecep. korosi, $i_{\text {corr }}(1)$ dgn. $w / c=0.40$ dan variabel $p$

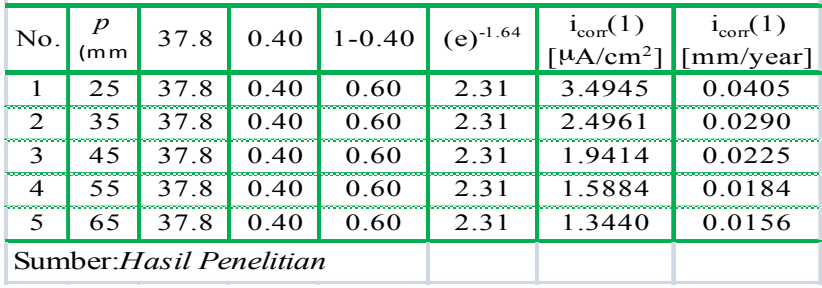

Tabel 2. Kecep. korosi, $i_{\text {corr }}(1)$ dgn. $w / c=0.50$ dan variabel $p$

\begin{tabular}{|c|c|c|c|c|c|c|c|}
\hline No. & $\begin{array}{c}p \\
(\mathrm{~mm}\end{array}$ & 37.8 & 0.50 & $1-0.50$ & $(\mathrm{e})^{-1.64}$ & $\begin{array}{c}\mathrm{i}_{\text {corr }}(1) \\
{\left[\mu \mathrm{A} / \mathrm{cm}^{2}\right]}\end{array}$ & $\begin{array}{c}\mathrm{i}_{\text {corr }}(1) \\
{[\mathrm{mm} / \text { year }]}\end{array}$ \\
\hline 1 & 25 & 37.8 & 0.50 & 0.50 & 3.12 & 4.7124 & 0.0547 \\
\hline 2 & 35 & 37.8 & 0.50 & 0.50 & 3.12 & 3.3660 & 0.0390 \\
\hline 3 & 45 & 37.8 & 0.50 & 0.50 & 3.12 & 2.6180 & 0.0304 \\
\hline 4 & 55 & 37.8 & 0.50 & 0.50 & 3.12 & 2.1420 & 0.0248 \\
\hline 5 & 65 & 37.8 & 0.50 & 0.50 & 3.12 & 1.8125 & 0.0210 \\
\hline
\end{tabular}

Sumber:Hasil Penelitian $\quad$ Note : $1 \mu_{\mathrm{A} / \mathrm{cm} 2}=11.6 \mu_{\mathrm{m} / \mathrm{y} \text { ear }}$

\section{Analisis Lentur Akibat Pengaruh Korosi}

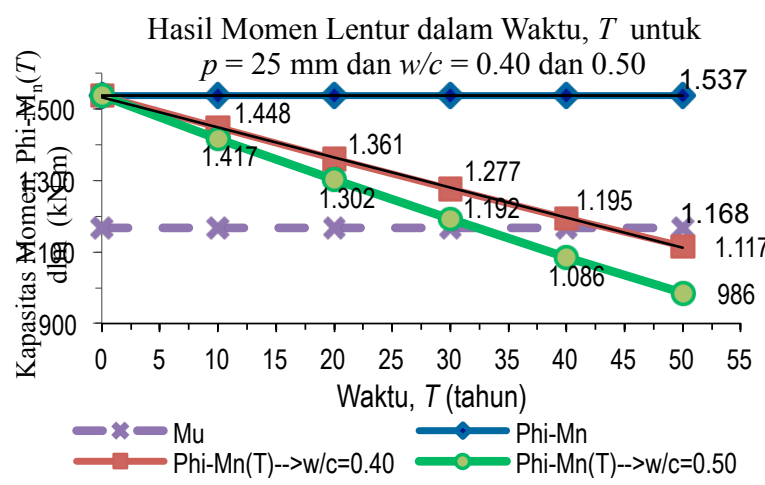

Gambar 14. Grafik Hubungan $M_{\mathrm{u}}, M_{\mathrm{n}}$ dan $M_{\mathrm{n}}(T)$ dan Waktu, $T$

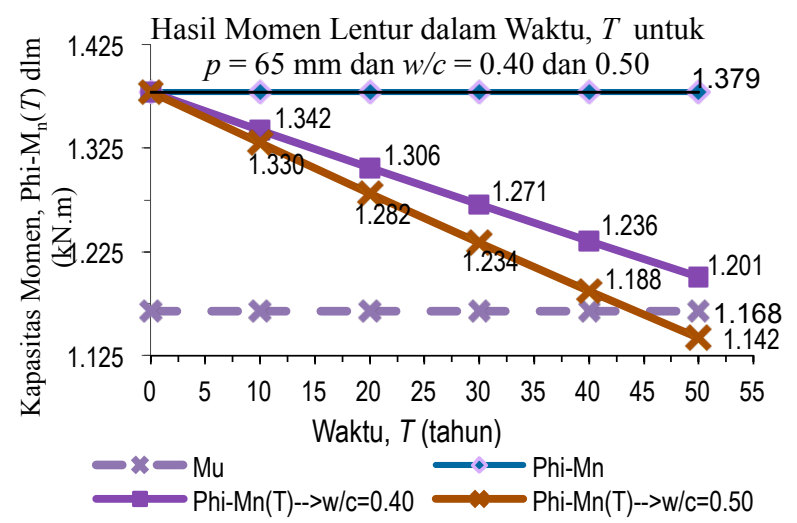

Gambar 15. Grafik Hubungan $M_{\mathrm{u}}, M_{\mathrm{n}}$ dan $M_{\mathrm{n}}(T)$ dan Waktu, $T$

* Analisis Geser Akibat Pengaruh Korosi

Kuat Geser Akibat Pengaruh Korosi (Beban AASTHO) 


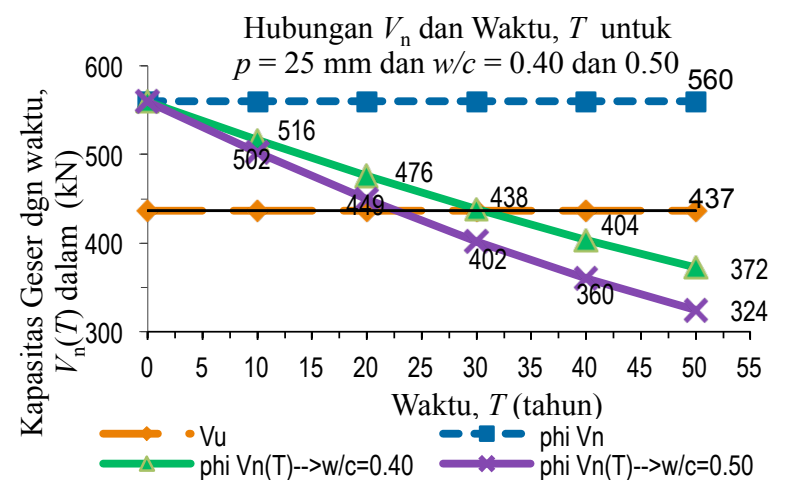

Gambar 16. Grafik Hubungan $V_{\mathrm{u}}, V_{\mathrm{n}}$ dan $V_{\mathrm{n}}(T)$ dan Waktu, $T$

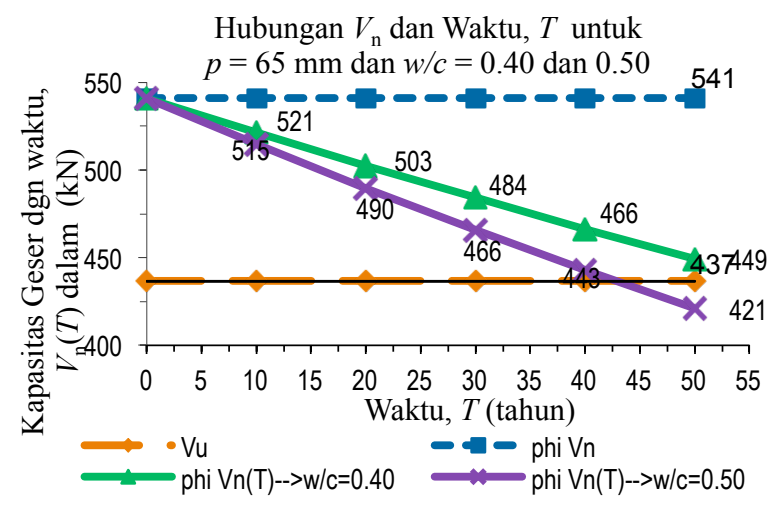

Gambar 17. Grafik Hubungan $V_{\mathrm{u}}, V_{\mathrm{n}}$ dan $V_{\mathrm{n}}(T)$ dan Waktu, $T$

\section{KESIMPULAN}

1. Untuk pembebanan AASTHO-LRFD, kapasitas lentur dan geser dengan selimut beton, $p=65 \mathrm{~mm}$ dan $w / c=0.40$ masih aman selama 50 tahun.

2. Kapasitas geser untuk pembebanan menurut AASTHO-LRFD dengan selimut beton, $p=65 \mathrm{~mm}$ serta ratio air-semen, $w / c=0.40$ dan 0.50 menghasilkan struktur yang aman $>50$ tahun.

3. Umur Struktur Sampai tahun ke-50, yaitu:

- Kapasitas Lentur Balok dengan Selimut Beton, $\mathrm{p}=25 \mathrm{~mm} ; \mathrm{w} / \mathrm{c}=0.50 \rightarrow 986$ $\mathrm{kN} . \mathrm{m}, \quad \mathrm{w} / \mathrm{c}=0.40 \rightarrow 1117 \mathrm{kN} . \mathrm{m}$

- Kapasitas Lentur Balok dengan Selimut Beton, $\mathrm{p}=65 \mathrm{~mm} ; \mathrm{w} / \mathrm{c}=0.50 \rightarrow 1142$ $\mathrm{kN} . \mathrm{m}, \mathrm{w} / \mathrm{c}=0.40 \rightarrow 1201 \mathrm{kN} . \mathrm{m}$

- Kapasitas Geser Balok dengan Selimut Beton, $\mathrm{p}=25 \mathrm{~mm} ; \quad \mathrm{w} / \mathrm{c}=0.50 \rightarrow$ $324 \mathrm{kN}, \mathrm{w} / \mathrm{c}=0.40 \rightarrow 372 \mathrm{kN}$
- Kapasitas Geser Balok dengan Selimut Beton, $\mathrm{p}=65 \mathrm{~mm} ; \mathrm{w} / \mathrm{c}=0.50 \rightarrow 421 \mathrm{kN}$, $\mathrm{w} / \mathrm{c}=0.40 \rightarrow 448 \mathrm{kN}$

\section{DAFTAR PUSTAKA}

DPU, (2004), "SNI T-12-2004, Tata Cara Perhitungan Struktur Beton untuk Jembatan, Penerbit DPU, Jakarta.

Darmawan M.S., (2006), "Model Korosi untuk Struktur Beton Bertulang di Lingkungan Air Laut", Seminar Nasional Rekayasa Perencanaan VIII 2006, UPN Jatim, Surabaya.

Ferguson P.M., (1981), "Reinforced Concrete Fundamentals", SI Version, $4^{\text {th }}$ Edition, Penerbit John Wiley \& Sons, Inc., USA.

McCormac Jack C., (2001), "Design of Reinforced Concrete", John Wiley and Sons, Inc., USA.

Mirza S.A., \& MacGregor J.G., (1979), "Variations in Dimensions of Reinforced Concrete Members", Journal of Structural Devision, ASCE, Vol. 105, No. ST4, pp. 751-766.

Stewart M.G. \& Rosowsky D.V., (1998), "Structural Safety and Seviceability of Concrete Bridges Subject to Corrosion", Journal of Structural System, ASCE, Vol. $4^{\text {th }}$, No. 4, pp. 146-155.

Roberth H.H., Raka I.G.P., Darmawan M.S. \& Wimbadi I., (2011), "Study on Corrosion Effect of Strength Reinforced Concrete Beams based on Probabilistic Theory", Seminar Nasional ATPW 2011, ITS, Surabaya.

Vu K.A.T. \& Stewart M.G., (2000), ”Structural Reliability of Concrete Bridges Including Improved Chloride-Induced Corossion Models", Structural Safety, Vol. 22, No. 4, pp. 313-333. 